\title{
Homicide in Southern Nigeria: \\ A survey of some aspects of the law and criminological data
}

\author{
By Dietmar Ertmann
}

\section{Introduction}

Nigeria, like many other developing countries, has inherited her legal system from the former colonial master - Great Britain. Law in general, and criminal law in particular is, however, a cultural product which has its life line in the moral order of a community and is doomed should it lose this vital link. It is with this background in mind that the present paper attempts to examine the role of one facet of the law - homicide - and its relation to the demand for norms (Normbedarf) of the contemporary Nigerian society.

For the purposes of this study I have looked at the substantive law of homicide as contained in the Criminal Code of Southern Nigeria ${ }^{1}$ as well as in numerous published and unpublished court cases. I have also attempted to collect empirical data from the files of the High Court of Lagos State and the Supreme Court of Nigeria.

The Supreme Court data represent all the appeals that were lodged at the court in 19722, a total of 90 cases with 114 of fenders and 95 victims. The High Court figures cover all the cases decided by that body between 1966 and 1974, a total of 33 cases with 43 offenders and 39 victims. Furthermore, the picture was supplemented by informal interviews with members of the judiciary, the police force and the general public.

As in other studies ${ }^{3}$ it was not possible to win the official cooperation of the police force so that their records remained unavailable. The archives of the Supreme Court therefore constitute the major nationwide source of information. With the exception of homicide involving armed robbery ${ }^{4}$ it can, however, be said that they give a fairly accurate picture of cases processed through the criminal justice system resulting in a conviction of murder since on such a charge defendants will almost invariably go on appeal when found guilty .

* The present article is based on my doctoral study "Die Behandlung der Tötungsdelikte in Südnigeria - Eine Analyse der Rezeption des englischen Rechts in Westafrika", Hochschulverlag Freiburg, 1980.

I The Criminal Code exists in three versions which, however, don't differ materially in the area under review. The Sections of the code are cited in accordance with the standard commentary of Brett-McLean 2 ed. 1974. In Northern Nigeria the law is contained in the Muslim inspired Penal Code which is excluded from this study.

2 The original study was carried out between October 1975 and April 1976 in Lagos, hence the new division of the country in subsequent years could not be incorporated.

3 e. g. Bienen [1974] Journal of Af rican Law 57. Since 1966, the Nigeria Police. Force has not published their Annual Report.

4 All cases involving armed robbery are tried before a special tribunal set up by the Robbery and Firearms Decree (Decree No. 47, 8. 8. 1970).

5 Variations might occur in relation to a verdict "not guilty on the grounds of insanity" and manslaughter. 


\section{Some characteristics of homicide cases in Southern Nigeria}

\section{(a) Regional Distribution}

\section{Table 1}

Appeals to the Supreme Court in $1972(\%)$

Lagos State 7

Western State

10

Midwestern State

11

East Central State

30

South Eastern State

32

Rivers State

10

\section{TOTAL}

$\approx 100 \quad(\mathrm{~N}=114)$

Looking at Table 1 it is striking how comparatively few homicides are committed in Lagos $^{6}$. The centre of crime is neither to be found in the populated and urbanized West but rather in the more rural East ${ }^{7}$. This is particularly visible in the former South Eastern State: it comprises only $12 \%$ of the population of Southern Nigeria, yet makes up for $32 \%$ of the homicide rate. In contrast, the former Western State houses almost a third of the population but participates only with $11 \%$ in the number of killings. The whole of Eastern Nigeria (i. e. the former East Central, South Eastern and Rivers State) houses less than half of the population but almost $3 / 4$ of the murderers. An analysis of the locus crimins reveals that $91 \%$ of all killings take place in rural areas.

There is also considerable variation from state to state regarding the features of the crime.

In urbanized Lagos the frequency of victim/offender relationship differs considerably even from the Western State, which at least originally, comprised the same ethnic group (Yoruba). Whereas in the capital $60 \%$ of the victims are either neighbours or friends of the offender and $30 \%$ strangers, the majority of victims (56\%) in the Western State are family members (spouses or other relatives). This might indicate the breakdown of the traditional family relationship in the capital city. The offender's immediate contact group is not any more the extended family but rather haphazardly chosen neighbours or colleagues at work. This, together with other criminogenic factors in Lagos may explain

6 The Director of Public Prosecutions estimated the number of armed robbery convictions not to exceed 15 a year in Lagos.

7 The provisional 1973 census estimates the population to be: Lagos State: 247 mill. Western State: 892 mill., Midwestern State 324 mill., East Central State 8,06 mill., South Eastern State: 3,46 mill. Rivers State: 2,23 mill. That puts the total population of Southern Nigeria at 28,33 mill. 
why the homicide rate - although comparatively small in comparison to the East - is more than double in Lagos than in the Western State $(32$ killings per 1 million inhabitants in Lagos as opposed to 14 per 1 million in the Western State).

Table 2 (infra) shows that the situation leading to the killing differs considerably in the various states.

The absence of crimes involving superstition in the East Central State seems rather remarkable. This fairly remonte part of the country would otherwise have appeared to be more prone towards traditional beliefs than Lagos. The figures from the Western and Midwestern State have to be treated with great caution due to their small numbers.

\section{(b) Personal features of of fenders}

Everywhere in the world women tend to be under-represented on the of fender side of the homicide statistic ${ }^{8}$. This tendency, however, is considerably reinforced in Southern Nigeria: only 2 female murderers (= less than $1 \%$ ) ended up in the criminal justice system, considerably less than in similar studies carried out in the Sudan ${ }^{9}$ and Uganda ${ }^{10}$. This becomes even more remarkable if one considers that Nigerian women generally play a very active role in life, ${ }^{11}$ in some ways even more active than their western counterparts. They dominate commercial life and are a force to be reckoned with in every phase of $\mathrm{Ni}$ gerian society. Furthermore some of the traditional forms of killing - witchcraft and poisoning - are of ten associated with women. ${ }^{12-14}$

\section{Table 2}

\begin{tabular}{|c|c|c|c|c|c|c|c|c|}
\hline States & $\begin{array}{l}\text { Spont. } \\
\text { Quarrel }\end{array}$ & $\begin{array}{l}\text { Rob- } \\
\text { bery }\end{array}$ & $\begin{array}{l}\text { Killing } \\
\text { by Police }\end{array}$ & $\begin{array}{l}\text { Super- } \\
\text { stition }\end{array}$ & $\begin{array}{l}\text { Acci- } \\
\text { dent }\end{array}$ & $\begin{array}{l}\mathrm{Re}- \\
\text { venge }\end{array}$ & $\begin{array}{l}\text { Tribal } \\
\text { warfare }\end{array}$ & Total \\
\hline Lagos & 37 & 29 & 9 & 14 & 9 & 3 & - & $\approx 100(\mathrm{~N}=35)$ \\
\hline Western & 44 & 33 & - & - & 22 & - & - & $\approx 100(\mathrm{~N}=9)$ \\
\hline Midwestern & 56 & - & -- & 33 & - & 11 & - & $\approx 100(\mathrm{~N}=9)$ \\
\hline $\begin{array}{l}\text { East } \\
\text { Central }\end{array}$ & 71 & 3 & - & - & 3 & 10 & 13 & $\approx 100(\mathrm{~N}=31)$ \\
\hline $\begin{array}{l}\text { South } \\
\text { Eastern }\end{array}$ & 68 & - & 5 & 16 & - & - & 11 & $\approx 100(N=19)$ \\
\hline Rivers & 80 & 10 & 一 & 10 & - & - & - & $\approx 100(\mathrm{~N}=10)$ \\
\hline
\end{tabular}

8 Wolfgang, Pattern of criminal homicide, Philadelphia, 1958 p. 284.

9 Fluehr-Lobban [1976] Journal of African Law 36.

10 Mushanga, Criminal homicide in Uganda, Kampala, 1974 p. 37.

11 Leith-Ross, African Women, London, 1965 p. 22 et seq.

12-14 Bohannan, African Homicide and Suicide, Princeton, 1960 p. 239. 
The employment rate of offenders is $95 \%$, a figure which must not be overemphasized since almost 2 in $3(62 \%)$ are farm labourers and are hence working at subsistence level. Alcohol plays only a minor role in killings. In only $8 \%$ of the cases the offender was known to have been drinking prior the act, in $5 \%$ the victim had been under the influence of intoxicating drink.

Table 3 Age of Offenders

\begin{tabular}{lc}
\hline & $\begin{array}{c}\text { Age of Offenders } \\
\%\end{array}$ \\
\hline Under 20 & 2 \\
$20-29$ & 41 \\
$30-39$ & 33 \\
$40-49$ & 20 \\
Over 49 & 4 \\
\hline TOTAL & $\approx 100$ \\
& $(\mathrm{~N}=99)$
\end{tabular}

Offenders in urban areas tend to be younger than in the countryside. Furthermore, $73 \%$ of the former are unmarried whereas only $40 \%$ of the latter fall into this category.

City dwellers also differ in their ability to speak English - the language of the court: $27 \%$ know how to read and write in English, 25\% speak Pidgin whereas in rural areas $72 \%$ are totally dependant upon interpretation into their mother tongue. Remarkable differences also appear when comparing urban and rural areas as to the months and time of the commission of the offence.

The main times for committing homicide are December/January and March/April. In Lagos there is also an increase in September, wheras in rural areas the duration of the spring peak extends into May. This may indicate a connection with the climatic changes. Harmattan, a hot dry wind carrying dust from the Southern Sahara blows in Lagos between December and February. The main rainy season starts in March and lasts through July/August. There is a second rainy season between September and October. In the beginning of the rainy season and the Harmattan the homicide rate increases noticeably in urban areas. This trend is not so remarkable in rural areas. It must, however, be remembered that most of the urban data come from one defined place - Lagos - wherease the figures for the countryside are averages from places that are as much as 500 miles apart. City dwellers, especially in Lagos, will spend most daylight hours (an average of 12 hours winter and summer alike) away from home. This may explain why $53 \%$ of all homicides in urban areas occur between 6 and $12 \mathrm{p}$. m. whereas only $28 \%$ happen during 
that time in rural areas. The peak time for killing in the open country is between 6 and 12 a. m. (40\%) There, the offender will be together with his kingroup at work.

$77 \%$ of the murderers knew their victim prior to the act and almost half of them $(41 \%)$ maintained friendly relationships with their victims before the incident. $61 \%$ killed spontaneously without planning and out of those who did plan $75 \%$ killed in the presence of other people.

Table 4 Victim is in relation to Offender

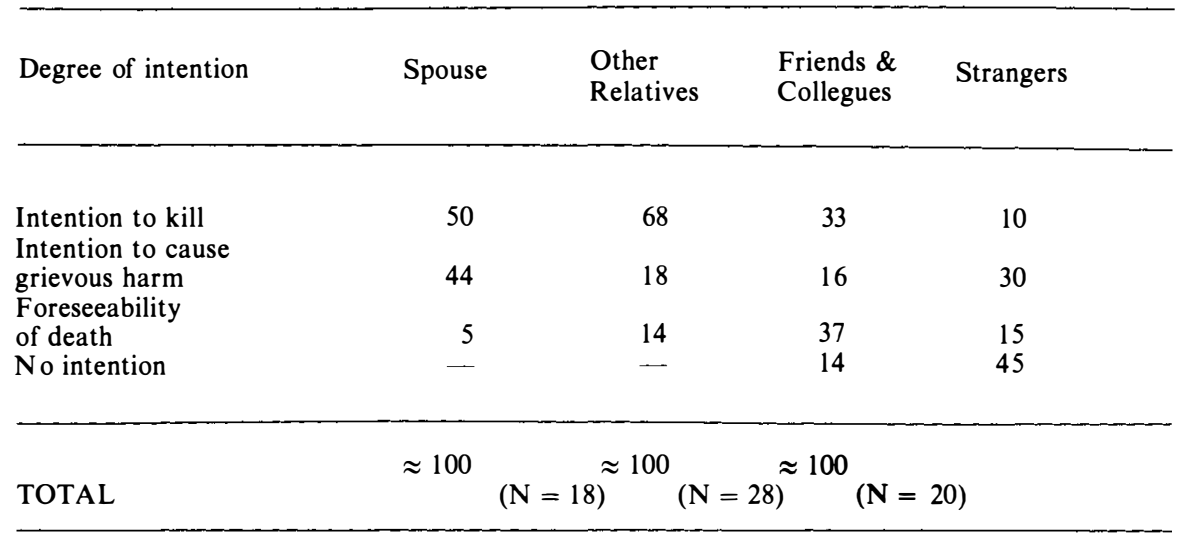

Married offenders - almost exclusively male, cf. supra - kill predominantly (70\%) female victims that are themselves married $(80 \%)$ whereas single offenders prefer male victims (68\%). 59\% of the vi tims of single of fenders are themselves married. Married offenders kill their spouses in $41 \%$ and other relatives in $26 \%$ of the cases, whereas the victims of single offenders are $29 \%$ friends and colleagues and $20 \%$ strangers.

\section{(c) Some data on reports to the police}

Virtually all the cases are cleared up because of the comprehensive reports lodged to the police. Cases in which the police have a first-hand knowledge of the crime or carry out extra investigation are of negligeable quantity. Reporting a case to the police, however, is a major enterprise considering that $88 \%$ of the investigating police stations are in the nearest district town, out of easy reach from the community of the accused ans his vic- 
tim. Given the lack of infrastructure the informant will alm ost invariably have to travel in person to the police station.

Informants usually come in groups, often led or detailed by a dignatary of the community.

Table 5 Reaction of the offender after the act

Attempts to commit suicide 2

Gives himself up to the Police

Arrested immediately by local people

50

Escapes, gives himself up later

4

Escapes and is arrested without defence

22

Escapes and is arrested after defence

TOTAL

$\approx 100$

$(\mathrm{N}=130)$

Often the informants bring the offender with them. It can be seen from Table 5 that in more than $2 / 3$ of the cases the of fender either gives himself up to the police or is handed over to the authorities by the accused's community. There is usually more than one day between the commission of the crime and the report to the police, on top of the fact, that the majority of rural killings are committed in the morning (cf. Table 6). Time enough, perhaps, for the elders of the community to decide whether a report should be made or whether the matter could be settled outside the of ficial system. Indeed, most of the people interviewed regarded such a screening process as standard practice.

It is remarkable that many of the traditional patterns of murder ${ }^{15}$ are not represented at all in my data: almost no child killings, hardly any executions of thieves, and very few killings involving witches ( $11 \%$, most of those come from Lagos). However, during my six months stay in Nigeria there were 9 reports in newspapers about ritual murders, all of which were particularly atrocious and therefore more noticeable. Traditionally, victims of these ritual murders were strangers, whose disppearance was not likely to be noted by any relatives. ${ }^{16}$ In conversations there were very often allusions to ritual murders in certain areas of the countries (in particular Jjebu-Ode in the Western State) and to mark certain occasions such as the death of a prominent chief, but it never resulted in police prosecution.

Furthermore, during my stay there were 4 reports in the newspapers about suspected poisoning. Yet corpses are usually only examined for alkaloid posions so that traditional

15 Clifford op. cit. p. 119.

16 Asuni, [1969] British Journal of Psychiatry, p. 1105. 
poisons are bound to go undetected during a post mortem ${ }^{17}$, according to a leading medical officer in Lagos.

It is also worth noting that the absence of these traditional killings is most marked in areas which are least developed, much less subject to the influence of Western civilisations and where the traditional community is still intact. One is therefore led to believe that the capital crimes that reach the criminal justice system only reflect what the community of the offender regards as deserving punishment. This can be further seen in the fact that the defendant hardly ever finds witnesses who are prepared to testify in his defence. In most cases the prosecution is able to present a whole army of witnesses, the defence has usually only the accused himself. This can be interpreted as a further indication that the community wants to see the defendant punished.

In the traditional Eastern community - and that is where most of the cases come from homicide was considered a very serious offenve indeed ${ }^{18}$ If somebody was killed as a result of a fight the killer usually had to flee the community with all his relatives and give up all his property or hang himself. Ostracism, today, does not have the same deterrent effect as is used to. Therefore the reaction of the community to the crime will change. Instead of banning him from communal life through expulsion which gave the offender little hope of survival they will now hand him over to the authorities and make sure that he gets convicted to court.

The objective - ridding the community of undesirable element - has remained the same, only the method has been adapted to modern needs.

This means on the other hand that crimes that are not considered to be blameworthy will hardly ever get reported hence hardly ever appear in court, and can therefore not be found in my data.

\section{Some aspects of the substantive law of homocide in Southern Nigeria}

After having examined some of the features of those who end up in the criminal justice systems it is important to look at the rules that are applied in these cases. Thus one may be able to determine which part the law plays in exercising social control and furthermore whether changes in the substantive law may be able to affect that pattern.

(a) The Criminal Law in Southern Nigeria is contained in a Criminal Code which is intended to be a more or less comprehensive piece of legislation. ${ }^{19}$ The doctrine of precedent as regards to English cases is somewhat obscure; it should therefore not be possible to introduce into Nigeria common law offences unknown to the Code and the courts

17 The only case of poisoning in my data involved drugs made in Europa.

18 Oputa, "Crime and the Nigerian Society", in African Indigenous Laws Nsukka, 1975 p. 9.

19 Aguda, Principles of Criminal Liability in Nigerian Law, Ibadan, 1965 p. 5.

,We have in Nigeria a Criminal Code which is means to be complete and exhaustiver Ogbuagu v. Police (1953) 20 N. L. R. 139 (per Bairamian J.) 
should not import extraneous glosses into it.. ${ }^{20}$ Nigerian cases however are treated as binding authorities. ${ }^{21}$

The Code has a colonial predigree. It was drafted for Queensland, Australia and was introduced to Nigeria by the colonial administration in $1916 . .^{22}$

(b) The relevant section regarding murder reads like this:

316. Except as a hereinafter set forth, a person who unlawfully kills another under any of the following circumstances, that is to say: -

(1) if the offender intends to cause the death of the person killed, or that of some other person;

(2) if the offender intends to do to the person killed or to some other person some grievous harm;

(3) if death is caused by means of an act done in the prosecution of an unlawful purpose, which act is of such a nature as to be likely to endanger human life;

(4) if the offender intends to do grievous harm to some person for the purpose of facilitating the commission of an offence which is such that the offender may be arrested without warrant, or for the purpose of facilitating the flight of an offender who has committed or attempted to commit any such offence;

(5) if death is caused by administering any stupefying or overpowering things for either of the purposes last aforesaid;

(6) if death is caused by wilfully stopping the breath of any person for either of such purposes;

is guilty of murder.

In the third case it

In the second case it is immaterial that the offender did not intend to hurt the particular person who is killed.

In the third case it is immaterial that the offender did not intend to hurt any person.

In the three last cases it is immaterial that the offender did not intend to cause death or did not know that death was likely to result.

This reflects vaguely the principles of English law in this field before the Homicide Act 1957. S. 318 further provides that where a person unlawfully kills another in circumstances which would constitute murder does the act which causes the death in the heat of passion caused by a sudden provocation and before there is time for his passion to cool is guilty of manslaughter only. Murder carries a mandatory death sentence (S. 319), manslaughter makes him liable to imprisonment for life (S. 325).

One of the interesting aspects of the definition of murder as given in S. 316 is subsection

20 Okonkwo, McLean, Cases on the Criminal Law, Procedure and Evidence in Nigeria, London, Lagos 1964 p. 221.

21 e.g. The State v. Ojovaretue, High Court Eastern Nigeria 0/78/66, 13. 3. 1967 (unpublished) cf. ljaliaye [1965] Nigerian Law Journal, p. 287.

22 For an account of the History of the Criminal Code see Morris "How Nigeria got its Criminal Code", 4 Journal of African Law, (1970), p. 137. 
(3): ${ }^{23}$ Death has to be caused by an act that is likely to endanger human life. It has been held in R. v. Idiong ${ }^{24}$ that an act was likely to endanger human life if a reasonable man would expect it to have such a result. It has been further held ${ }^{25}$ that a cut with a dirty knife would make a reasonable man expect death to result.

Under Nigerian law, therefore, we are faced with the situation that an offender could be convicted of murder, if in the course of an unlawful fight he injures his victim with a dirty knife, the victim develops gangrene and dies because proper medical treatment is not available. The definition of murder, hence, can be very wide indeed.

(c) The rules relating to provocation on the other hand, tend to be interpreted rather restrictively. Under English law the mode of retaliation has to be proportionate to the provocation given by the other side. ${ }^{26}$ In an early Nigerian case ${ }^{27}$ it was submitted to the court that the definition of what constitutes provocation in law should be found in the code rather than in the common law. However, the court ref used to enter into such an argument by saying:

"We cannot subscribe to this proposition and we think that the broad and well established principles of English law must be applied..."

This, however, was a colonial decision. The winds of change blew and an independent Nigerian court had to decide the same question..$^{28}$ The judges said:

"We are in agreement with the learned Director of Public Prosecutions who argued before us that the duty of the courts in Nigeria is to interpret the Criminal Code free from interpolations and refrain from propounding the common law of England and in this particular case, where it has been held as a matter of law by the courts in England that the mode of retaliation or resentment by an accused person must not be out of proportion to the provocation given by the other side... the Nigerian courts have followed the English decisions rather than interpreted their own Criminal Code."

The court then went on examining decisions rendered under the Criminal Code of Queensland (29) which contains identical provisions. Upon perusal of these cases, the judges come to the following conclusions:

"It is difficult to accept that proportionality must be excluded."

The winning argument which the Nigerian judges seem to have found in the Queensland decisions was indeed very simple:

23 Subsection (4) - 6 all deal with subgroups of subsection (1) - (2) and are superfluous. They have as far as it is known never been used in court.

24 (1950) 13 W. A. C. A. 30.

25 R. V. Paki (1955) 21 N. L. R. 63: "The defendant has never I am sure, heard the name of Lord Lister ..." (per Bairamian. J.).

26 Mancini v. DPP [1942] A. C. 1. Holmes v. DPP [1946] AC 588. There seems to be a move away from this position in England. In Ng Yiu-nam v. R [1963] Crim. 1. R. 850 the Supreme Court of Hong Kong declared that it was an error to make retaliation proportionate to the provocation a separate and distinct element which had to exist before the defence could succeed.

27 R. v. Nwanjoku, (1937) 3 W. A. C. A. 208.

28 Obaji v. The State (1965) N. M. L. R. 417. 


\section{(Per Marcossen in R. v. Sabri Fsa ${ }^{29}$ )}

"The provisions ... of the criminal code introduced no change into the law and did no more than state in statutory form what was the common law of England."

In R. v. Herlihy ${ }^{30}$ the argument is even shorter:

"(Per Mansfield and Mack)

The Code reproduces the common law doctrine of provocation."

So, in effect, we are back to the "broad and well established principles of English" law which the judges set out to avoid. ${ }^{31}$

The Code mentions provocation at various places. S. 317 lays down the rule that killing upon provocation renders the offender guilty of manslaughter. S. 283 defines the term provocation:

"The term 'provocation', used with reference to an offence of which an assault is an element, includes, except as hereinafter stated, any wrongful act or insult of such a nature as to be likely, when done to an ordinary person, or in the presence of any ordinary person to another person who is under his immediate care, or to whom he stands in a conjugal, parental, filial, or fraternal relations or in the relation of master or servant, to deprive him of the power of self-control and to induce him to assault the person by whom the act or insult is done or offered.

When such an act or insult is done or offered by one person to another or in the presence of another to a person who is under the immediate care of that other, or to whom the latter stands in any such relations as aforesaid, the former is said to give the latter provocation of an assault.

A lawful act is not provocation to any person for an assault.

An act which a person does in consequence of excitement given by another person in order to induce him to do the act and thereby to furnish an excuse for commiting an assault is not provocation to that other person for an assault.

An arrest which is unlawful is not necessarily provocation for an assault, but it may be evidence of provocation to a person who knows of the illegality."

This rather elaborate definition makes it clear that it requires application for all offences of which an assault is an element. Since assault is a necessary transitional stage for homicide it should be beyond doubt that it is relevant for the question whether murder will be reduced to manslaughter on the grounds of provocation. ${ }^{32}$

Nowhere in s. 283 , is there a separate requirement of proportionality. S. 283 is an abstract provision giving a definition of what is considered a provocation in law. It does not spell out the consequences for the various offences committed upon provocation. This task is left to s. 317 for the offence of murder and to s. 284 for the offence of as-

29 R. v. Sabri Fsa [1952] Q. S. R. 269; R. v. Herlihy [1955] Q. S. R. 18.

30 [1955] Q. S. R. 18.

31 Much more convincing arguments about proportionality from the point of view of the code a re to be found in a Northern decision John v. Zaria N. A. (1959) N. R. N. L. R. 43 followed in the State v. Ukpabi, High Court East Central HV/28c/71 (unpublished).

32 Obaji v. The State [1965] I All N. L. R. p. 269. 
sault. S. 317 simply stipulates, that a killing that would constitute murder is regarded as manslaughter if done in the heat of passion caused by a sudden provocation and before there is time for the passion to cool.

Neither s. 283 nor s. 317 mention a separate requirement of proportionality. S. 284, however, is more elaborate. It reads:

A person is not criminally responsible for an assault committed upon a person who gives him provocation for an assault it he is in fact deprived by the provocation of the power of self-control, and acts upon it on the sudden and before there is time for his passion to cool; provided that the force used is not disproportionate to the provocation and is not intended, and is not such as is likely, to cause death or grievous harm. S. 284 is confined to the offence of assault. It is, furthermore, a complete defence, acquitting the offender of the crime charged. Thus it is totally different in kind from s. 318 which only mitigates the guilt in a homicide case. It is therefore quite understandable that the application of the defence should be restricted to cases of proportionate retaliation.

Hence, s. 284, cannot be used to help introducing proportionality into the defence of provocation in a homicide case. On the contrary, if proportionality were an inherent element of provocation it would hardly be necessary to include it specifically in s. 284 for the legislature is not deemed to waste its words or say anything in vain. The presence of proportionality in a rule dealing with the consequences of an assault and the absence of it in sections concerning the general definition of provocation and its consequences for homicide must indicate that the legislator has meant it to be only of application in the specific circumstances of assault.

Proportionality is therefore not a separate requirement in examining whether or not murder is reduced to manslaughter. ${ }^{33}$

In the case of Obabi v. The State ${ }^{34}$ the Nigerian Supreme Court has held, following Bank of England v. Vagliano Brothers. ${ }^{35}$

"In the interpretation of a statute ... the correct course is in the first instance to examine the language of the statute and to apply its natural meaning influenced by any consideration derived from the previous state of the law and not to start with inquiring how the law previously stood and thus assuming that it was probably intended to leave it unaltered."

But, with the greatest respect to the learned judges, it seems to me that Nigerian courts contravene this principle all too often: some courts apply English Law of provocation directly ${ }^{36}$ ignoring the definition of the Code, some even ${ }^{37}$ use the particularly restricted in-

33 see also Okonkwo, Naish Criminal Law in Nigeria, London, 1964 p. 244, Brett, McLean Criminal Law and Procedure of the Six Southern States of Nigeria, 2 ed. London, 1974 para. 1818.

34 [1963] I All N. L. R. 269.

35 [1891] A. C. 102.

36 The State v. Uzokwe High Court East Central HOW/23c/71 10.11. 71 (unpublished).The State v. Ejiama High Court East Central HOW/47c/72, 27. 3.73 (unpublished). The State v. Joga, High Court West AB/2c/ 72, 28. 6.72 (unpublished).

37 The State v. Akpan, High Court South East, C/40C/71, 27. 7. 71 (unpublished). 
terpretation of R. v. Duffy. ${ }^{38}$ Many other ${ }^{39}$ draw the analogy to s. 284 overlooking that it is meant to govern a totally different situation and in spite of the fact that judges in Queensland have long rejected the idea that s. 284 can be applied in homicide cases. ${ }^{40}$ Due to the incorporation of what is basically an English rule into the Nigerian criminal law the defence of provocation is severely limited.

(d) This remarkable preference for English law over their own Criminal Code can be seen in many other instances. All too often, when examining the Code, the judges conclude:

"this may look a little diferent from English law but I don't think it is meant to be" ${ }^{41}$ Defences which have no exact corollary in English law such as s. 26 are totally ignored.

s. 26 lays down the defence called extraordinary emergencies.

It reads:

Subject to the express provisions of this code relating to acts done upon compulsion or provocation or in self-defence, a person is not criminally responsible for an act done or omission made under such circumstances of sudden or extraordinary emergency that an ordinary person possessing ordinary power of self-control could not reasonably be expected to act otherwise.

This, admittedly, recalls the common law defence of necessity. It is not quite clear to what extent the rule is applicable in England. ${ }^{42}$ However, it was raised as a defence against a charge of homicide in R. v. Dudley and Stephens ${ }^{43}$ and failed as a complete defence. In that case the learned judge described the situation in which the accused found themselves: ${ }^{44}$

"It must not be supposed that in refusing to admit temptation to be an excuse for crime it is forgotten how terrible the temptation was, how hard in such trials to keep the judgment straight and the conduct pure. We are of ten compelled to set up standards we cannot reach ourselves (sic!) and to lay down rules which we could not ourselves satisfy. But a man has no right to declare temptation to be an excuse though he might himself have yielded to it nor allow compassion for the criminal to damage or weaken in any manner the legal definition of crime."

In comparing this passage to s. 26 the difference becomes immediately noticeable: the Criminal Code expects an ordinary person to act reasonably under the circumstances, whereas, the judges in R. v. Dudley and Stephens set up standards which such a person is

38 [1949] 1 All E. R. 932.

39 The State v. Abu 1977 ECSLR 175. The State v. Ukpabi High Court East Central HU/18c/171, 26. 5. 71 (unpublished). The Republic v. Peters High Court Lagos LA/3c/66 11. 3. 66 (unpublished). The State v. Konyeyasu, High Court East Central HOW/18c/M. 8. 9. 71 (unpublished).

40 Howard, 33 Australian Law Journal, 323 (326)

41 Trial judge in R. v. Omoni 12 W. A. C. A. 511

42 Kenny, Outlines of Criminal Law, 19. ed; Cambridge 1966 para 47, cf. James Stephens History of Criminal Law, London $1883 \mathrm{II}$, p. 109 "It is impossible to imagine cases in which the expediency of breaking the law is so overwhelmingly great that people might be justified in breaking it".

4314 Q. B. D. 273.

44 supra p. 288. 
not expected to reach. The drafter of the Criminal Code, Griffith, explained why he inserted s. 26 into the Code. ${ }^{45}$

"This section gives effect to the principle that no man is expected (for the purpose of the Criminal Law at all events) to be wiser of better than all mankind. It is conceived that it is a rule of the Common Law as it is undoubterly a rule upon which any jury would desire to act. It may perhaps be said that it sums up nearly all the Common Law rules as to excuses for an act which is prima facie criminal. ${ }^{46}$

Griffith argues that s. 26 represents a Common Law rule without giving further substantiation to that argument: a rule upon which any jury would desire to act upon is not per se of the Common Law. Having regard do R. v. Dudley and Stephens (supra) it rather seems that he wanted to modify the Common Law, but did not dare admit to that in order vertly changed the rigidity of the old law. Yet courts in Nigeria invariably maintain that vertly changed the rigidity of the old law. Yet courts in Nigeria invariably maintaint that the complete def ence of necessity does not apply to homicide, relying on R. v. Dudley and Stephens (supra) ${ }^{47}$ It could be argued that the defence of extraordinary emergencies is subject to the express provision of the Code relating to acts done upon compulsion (s. 32) and compulsion is no defence against homicide. However, such an interpretation would run contrary to Griffiths's own explanation of the rule:

"no man is expected (for the purposes of the Criminal Law . . .) to be wiser or better than all mankind..."

Furthermore if s. 32 is not applicable in law it cannot modify the applicability of s. 26 of homicide. The introductory sentence in s. 26 only gives way to the old principle of "lex specialis derogat legem generalem". If, however, the special rule is not applicable in law it cannot be used as a derogation of the general one. ${ }^{48}$ Various cases in which the defence of extraordinary emergencies could have been raised ${ }^{49}$ have come before the courts, yet the defence has never even been disussed.

(e) But s. 26 is not the only undiscovered treasure in the Criminal Code. Under the old Common Law mental abnormality was only taken into account if it amounted to a disease of mind under the McNaughten Rules. ${ }^{50}$ This state of affairs was changed in England by s. 2 of the Homicide Act 1957 which - among others - introduced the defence of diminished responsibility.

S. 2 reads:

"Where a person kills or is a party to the killing of another he shall not be convicted of murder if he was suffering from such an abnormality of mind (whether arising from a condition of arrested or retarded development of mind or any inherent causes

45 according to Carter, Criminal Law of Queensland, 4. ed. Sydney 1974 p. 78.

46 One of the arguments against Stephens Criminal Code Bill in England has always been that it changed substantially the Common Law, Holdsworth, A History of English Law, p. 147 et seq.

47 Aguda, p. 143.

48 See also, Brett, McLean op. cit. para. 1399.

49 Alagba v. The King (1950) 19 n. L. R. 128; R. v. Obodo (1958) 4 F. S. C. 1.

50 Beck, Die vorsätzliche Tötung im englischen Recht, S. 160. 
or induced by disease or injury) as substantially impaired his mental responsibility for his acts and omissions in the killing."

Lord Parker C. J. ${ }^{51}$ remarked:

"It appears to us to be wide enough to cover the mind's activities in all its aspects, not only the perception of physical acts and matters and the ability to form a rational judgment as to whether an act is right or wrong but also the ability to exercise this power to control physical acts in accordance with that rational judgment."

It has often been deplored in Nigeria ${ }^{52-55}$ that the Criminal Code does not recognise the defence of diminished responsibility. The Criminal Code does, however, contain a provision, which, though different in construction might serve the same end: to take mental disturbances not amounting to insanity into account.

S. 28 stipulates:

A person is not criminally responsible for an act or omission if at the time of doing the act or making the omission he is in such a state of mental disease or natural mental infirmity as to deprive him of capacity to understand what he is doing, or of capacity to control his actions, or of capacity to know that he ought not to do the act or make the omission.

A person whose mind, at the time of his doing or omitting to do an act, is affected by delusions on some specific matter or matters, but who is not otherwise entitled to the benefit of the foregoing provisions of this section, is criminally responsible for the act or omission to the same extent as if the real state of things had been such as he was induced by the delusions to believe to exist.

In the Queen v. Eriyamremu ${ }^{56}$ the accused had killed her grandchild. The little girl was an albino, which is considered to be an abomination by some tribes in Nigeria. The accused gave the following evidence in court:

"... I used to serve juju ... I am the grandmother of Oyinbo. Between the night of Tuesday and Wednesday my mates in witchcraft came to my house and instructed me to kill my granddaughter Oyinbo and I killed her that very night with a stick which is still in my room and before this done I held her two legs swinged her round my head and knocked her on the floor three times. All these been done in the night. After the death I use a matchet to cut her two legs and I threw the matchet in a brook."

The court perused the law of insanity and argued:

". . . even if it is arguable that at the time she killed the girl she was afflicted with mental infirmity which deprived her of capacity to know that she ought not to kill the girl on balance of probabilities the infirmity was not natural and that it was induced by the prisoner's worship of juju and/or witchcraft."

5112 W. A. C. A. 511.

52-55 cf. Okonkwo, Naish, op. cit. p. 139, The State v. Anjakara 1968 High Court Western Nigeria, A K 36c/66 (unpublished).

56 [1959] W. R. N. L. R. 270. 
Having found her not falling under the category of s. 28 para I the judge could have examined s. 28 para II arguing that she was suffering from a delusion that affected her in such a way that she felt compelled to follow the orders of her companions in witchcraft. It is doubtful whether that would have materially altered the outcome of the decision, yet on a charge of murder it seems worth trying.

In another case ${ }^{57}$ the accused slew his mother-in-law with an axe. Throughout his interrogation by the police and in court he maintained that he killed a lizard and that his mother-in-law was a witch who turned herself into the animal. He submitted to the court that while he killed the lizard he had no idea that it was his mother-in-law. While it was argued on his behalf that he had a history of mental disturbances the defence failed to persuade the court that his mental disability came within the provisions of s. 28 para I. S. 28 para II was never raised.

The McNaughten Rules contain a similar provision to s. 28 para. II. Since the introduction of the defence of diminished responsibility, however, it has been used very little indeed $^{58}$ The same is true for the identical provision s. 27 para. II of the Queensland Criminal Code since the defence of diminished responsibility was introduced there ${ }^{59}$. This, together with the wording of s. 28 para II seems to suggest that in spite of the difference in the legal consequences the field of application is perceived to be somewhat similar to the defence of diminished responsibility and in the absence of legislative initiative it should be used to create more flexibility in the law relating to mentally unbalanced offenders.

\section{Conclusion}

The criminal law in Nigeria in general and the law of homicide in particular is largely the product of the European legal tradition. The criminological data of homicide suggest no great difference between crime patterns in Nigeria and elsewhere in the world. Could it be that the kind of criminality found is the product of the kind of law applied in these cases? The traditional Nigerian society considered homicide to be a particularly heinous crime $^{60}$ for which the indigenous community had an elaborate set of sanctions. Many of them cannot fulfill their functions any more since they were essentially based on the interdependence between the offender and his native community. Formerly life in a community was the only guarantee for survival; today, the growth of infrastructure has made migration into the anonymity of urban centres possible. Expulsion - the most widely used form of punishment ${ }^{61}$ in the traditional society - is not any more a serious threat to

57 The Queen v. Udoh High Court Lagos LA/23c/71; 27. 9. 71 (unpublished).

58 Williams, Criminal Law, General Part 2 nd. ed. London, 1961 p. 500.

59 Carter, op. cit. p. 79 et seq.

60 Oputa, op. cit. p. 9.

61 Oputa, op. cit. p. 9 et seq. 
life but rather an inconvenience. This, however, has not led to a decline of the indigenous jurisdiction - the traditional society has only adapted its sanctioning system. Instead of expelling the murderer from the community into the wilderness he is now handed over to the police to be dealt with. But the control of the definition of crime is still - in the majority of cases - in the hands of those who have administered justice for centuries. The modern law has not replaced the traditional forms of social control, it has only been incorporated into the traditional sanctioning system.

The vast majority of cases that reach the criminal justice system come from areas where there is little or no police control and where the traditional society has not yet disintegrated. The kind of cases that come up would have been regarded as blameworthy under the old customary rules - mostly killings in the course of sudden and unpremeditated fights. Killings that would be defined as criminal under the Code but are regarded as justifiable under customary law are conspicuously absent in the crime statistics but those who are in contact with native communities consistently assert their existence: execution of thieves, witch-killings, twin-killings, ritual murders.

The reaction of the Criminal Code and the courts to unpremeditated killing is rather harsh indeed for European standard. The old felony-murder rule is alive and well and in conjunction with a rather limited interpretation of the rules regarding provocation leads to an extensive application of the law of murder. In view of the capital punishment awaiting the offender ${ }^{62}$ this would seem to be an overreaction in many Western eyes. It appears however, that this type of reaction is acceptable to the community, otherwise the offender would not be handed over to the police.

Where traditional convictions conflict with the definition and interpretation of the Criminal Code the indigenous community will not resort to the criminal justice system as a means of conflict solution. Therefore only very few cases involving traditional beliefs actually end up in court and if they do they come from urban areas where the old powers of social control have lost some of their strength.

The attitudes of courts towards witcheraft and simular forms of traditional beliefs have often been criticized. ${ }^{63}$ The courts have always justified their refusal to take traditional beliefs into account as justifying or mitigating circumstances with the argument that it would lead to a breakdown in social order. ${ }^{64}$ This, however, assumes that social control is - at least to a large extent - exercised by the courts. The figures, however, suggest the contrary. As long as the criminal law insists on a standard of reasonableness in cases including witchcraft and the like that is more geared towards the man in the Clapham omnibus than to the man in a mammy-lorry somewhere between Lagos and Enugu, they

62 Milner, Nigerian Penal System London, 1972 p. 73 calculates, however, that only one in ten convicted murderers is actually executed. The inflation of death sentence has enticed the authorities to use the prerogative of mercy extensively in order not to reduce the deterrent effect of capital punishment through the application in "ordinary" cases. Death sentences in cases involving armed robberry are usually carried out.

63 e. g. Seidman, (1966) International and Comparative Law Quarterly, 1135.

64 e. g. R. v. If ereonwe (unpublished) cited in R. v. Gadam (154) 14 W. A. C. A. 442: "It would be a dangerous precedent to recognise". 
will be dealt with outside the criminal justice system. In order to fight witch-killings and other forms of traditional homicide the law must lower its standard to accommodate the values of the community. Only then will there be a chance that such offences might enter into the criminal justice system.

The reception of a legal system which is alien to the vast majority of the population entails many difficulties. In those areas where the value system of the Criminal Code was roughly comparable to that of the indigenous community it has been used to serve the ends of the old system, where, however, the traditional value system is not in accordance with the law, the law, through lack of enforcement agencies, has lost the battle. If it doesn't want to lose the war it must seek to accommodate these values within its framework.

\section{Bibliography}

\section{Books}

Aguda, T. A., Principles of Criminal Liability in Nigerian Law (Ibadan, 1965)

Bohannan, P., African Homicide and Suicide (Princeton, 1960)

Brett and McLean, The Criminal Law and Procedure of the Six Southern States of Nigeria edited by T. Aguda and C. O. Madarikan, 2nd edition, (London, 1974).

Carter, R. F., Criminal Law of Queensland 4th edition, (Sydney, 1974)

Clifford, W., An Introduction to African Criminology (Nairobi, 1974)

Holdsworth, Sir W., A History of English Law (London 1965)

Kaiser, G., Kriminologie 4th edition, (Karlsruhe, 1979)

Kenny, Qutlines of Criminal Law edited by J. W. C. Turner, 19th edition (Cambridge 1966)

leith-Ross S., African Women (London, 1965)

Milner, A., Nigerian Penal System (London 1972)

Mushanga, T., Criminal Homicide in Uganda (Kampala, 1974)

Okonkwo, C. O., and Naish, M. E., Criminal Law in Nigeria (London 1964)

Stephens, Sir. J., The History of English Criminal Law (London 1883)

Williams, G., Criminal Law General Part 2nd edition, (London, 1961)

Wolfgang, M., Patterns in Criminal Homicide (Philadelphia, 1958)

\section{Articles}

Asuni, T., "Homicide in Western Nigeria" [1969] British Journal of Psychiatry 1105 Bienen, L., "Criminal Homicide in Western Nigeria" [1974] Journal of African Law 57 
Fluehr-Lobban, C., "An Analysis of Homicide in Afro-Arab Sudan" [1976] Journal of African Law 47

Ijalaiye, D. A., "Precedents in the Nigerian Courts" [1965] Nigerian Law Journal 287

Morris, H. F., "How Nigeria Got its Criminal Code" [1970] Journal of African Law 137

Oputa, S. A., "Crime and the Nigerian Society", in African Indigenous Laws (Nsukka, 1975)

Seidman, R., "Mens Rea and the Reasonable African" [1966] International and Comparative Law Quarterly, 1135 
The agricultural cooperative movement of Korea has become a mere instrument for the implementation of the Government's agricultural policy. As this policy favours industrialisation at the expense of the rural areas, the movement has become more an instrument for the exploitation of farmers than for their promotion. In fact there is forced membership and members' democratic control is lacking. The same applies to the second parastatal "self-help"-movement, called Saemaul-Undong or New Village Movement. It serves to a great extent political purposes by trying to exert control upon urban and rural communities and by brainwashing the public with a kind of fascist ideology.

The only indigenous and autonomous private sector self-help movements which have been able to survive until now are the credit unions and a number of smaller organizations on a denominational basis.

In a repressive political environment like in South-Korea any foreign development assistance which aims at the development of self-help activities should neither be given on a government to government basis, nor should it go to the officialized parastatal structures.

\section{Homicide in Southern Nigeria:}

A survey of some aspects of the law and criminological data By Dieter Ertmann

Even after the end of the colonial area Nigeria is still battling with the heritage of colonialism. The criminal law of Nigeria is based for most parts on the English law of the turn of the country. Very little attempt has been made to accomodate traditional beliefs and values. At first sight the crime structur seems to be patterns elsewhere in the world. There is, however, evidence to suggest that some forms of crime are filtered out by an informal method of social control. Crimes which the traditional African society does not approve of, come up for prosecution in the state courts - an adapted form of the age - old sanction of ostracism that was used for heinous crimes. Acts done in contravention of the state law, yet innocent in the eye of the immediate environment of the offender are conspicuously absent from any statistics. The harsh reaction of the state law towards unpremedicated killing - unacceptable as it may be to a modern European lawyer - seems not to violate in principle the feelings of the traditional society. The marked preference of Nigerian courts for - sometimes obsolete - English common law over the Nigerian Criminal Code remains unnoticed by the average Nigerian, although the Criminal Code offers in many respects better and more flexible solutions to the problems than the old common law. The informal filter of social control only comes into operation when the state law insists on standards that are more geared towards the man in the Chapham omnibus than to the man in a mammy lorry between Lagos and Enugu. Where the traditional value systems is not in accordance with the law the traditional society will do its best to settle the matter outside the court room. 